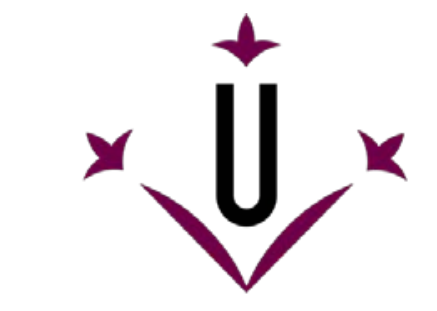

Universitat de Lleida

Document downloaded from:

http://hdl.handle.net/10459.1/66794

The final publication is available at:

https://doi.org/10.1007/s10610-016-9313-2

Copyright

(c) Springer Verlag, 2016 


\section{Municipal ordinances and street prostitution in Spain}

Carolina Villacampa $1, *$

Email cvillacampa@dpub.udl.cat

AQ1

1 Department of Public Law, University of Lleida, Lleida, Spain

\section{Abstract}

Beginning with the civic ordinance enacted in Barcelona in 2005, in the first decade of the twenty-first century, most big and medium-sized cities in Spain enacted municipal ordinances prohibiting various types of uncivil behaviour in the street. The stated goal of all these municipal regulations was to promote urban safety and the civic use of public space. However, in some cases these prohibitions have gone beyond this goal and had deeper, at times even contrary, effects on some of the activities they are intended to regulate. An analysis of the effects of banning street prostitution through municipal ordinances in Spain shows not only that the trade of sexual services in the street has not disappeared, but also that the conditions of police control in which street sex workers must operate have worsened. The lack of effectiveness of these regulations to discourage sex workers from offering their services in the street may explain the recent change in municipal policy attitude towards this issue, which is shifting from a soft prohibitionist approach to an abolitionist one. At the national level, although the recently passed Citizen Safety Act seems to take an abolitionist approach to this matter, materially speaking it is very close to prohibitionist schemes for dealing with street prostitution.

\section{Keywords}

Abolitionism

Municipal ordinances 
Prohibitionism

Prostitution

Sex work

\section{Introduction}

Urban safety is not a concept that has seen widespread penetration in the context of the control of crime and anti-social behaviour in Spain or southern Europe in general (Recasens et al. 2013). Whereas in the United States, the wide margins of control granted to specific security managers by the Patriot Act have led to the large-scale adoption of policies designed to prevent such behaviour with a view to maintaining a broad sense of urban safety that, for practical purposes, is identified with the notion of homeland security (Light 2002), in countries such as Spain, the concept of urban safety is viewed in a more domestic sense. It is associated with public safety and civic or civilised coexistence and, to date, has been rooted in the municipal reality.

Spain has more of a tradition of concepts such as "citizen safety" or "public safety", which have been instrumental in the adoption of administrative regulations aimed at maintaining safe spaces in a municipal environment, but whose conceptualisation has not always been clear. Initially, the concepts of public safety and citizen safety were considered to be synonymous (Constitutional Court Judgment 325/1994) and were identified with the concept of public order, as being equivalent to maintaining the population's peace of mind. Subsequently, attempts were made to distinguish between the two concepts, although recently the boundaries appear to have blurred once again. Public safety, the maintenance of which the Spanish Constitution attributes exclusively to the state, is identified with protecting people and goods and ensuring citizen safety (Carro 1990; Barcelona 1995). Although citizen safety is not defined in Spanish law, it is listed in the Constitution as one of the tasks assigned to law enforcement agencies. It is considered to be a component of public safety and is identified with a situation that affords people the necessary sense of security and stability to enable them to exercise freely and responsibly the rights and freedoms afforded to them by the Constitution. In an attempt to differentiate it from public safety, it was more strictly identified with the protection of goods and people from violent or aggressive acts, that is, dangerous situations directly associated 
with police work or services or the "safety police" (Gracia 2008). However, more recently, Article 1 of the 2015 Citizen Safety Act identifies it not only with the protection of people and goods, but also maintaining the population's peace of mind.

Not so different semantically speaking, given the scope with which the terms "public safety" and "citizen safety" were conceived, is the concept of citizen or civic coexistence. This is the concept used in many of the municipal ordinances seeking to regulate prostitution to some extent in Spain passed in the first decade of the twenty-first century. Broadly speaking, civic coexistence can be understood as the relationship amongst residents and between them and their urban environment. This includes both a closely defined concept of citizen safety (namely, that handled by the safety police) and the notion of civic coexistence associated with public order-actions aimed at protecting goods or people and ensuring peace of mind - and the use of public space.

Whether based on the idea of citizen safety or on the idea of civic coexistence, both concepts have been used in Spain to implement a series of administrative regulatory mechanisms that have proved to be instrumental in maintaining a certain level of safety, in overcoming barriers to enforcing punitive administrative, but not criminal, law. In response to growing safety demands, and in light of the subjective perception of insecurity inherent to post-industrial societies, a series of preventive measures have been drawn up, which, through the use of administrative law sanctions, tend to separate individuals considered to be a potential threat to the safety of public spaces. The same ideas imposed by criminal law on dangerousness, which acts preventively, have prevailed in the administrative law penalising dangerousness. Given this subjectively felt context of insecurity, the use of public space has been regulated on the basis of a restrictive idea of citizenship fundamentally rooted in nationality (De Lucas 2015) that segregates individuals who do not belong to this category and excludes those considered to be undesirable. Whether based on urban safety, citizen safety or civic coexistence, this type of regulation has led to the segregation and control of certain individuals, namely the "failed citizens" or "non-citizens" (Bickford 2000; Wacquant 2009; Beckett and Herbert 2010). Consequently, the public space has ceased to be a place for everyone and has become the exclusive domain of certain citizens; in so doing, it has ceased to be a truly public space. 
These types of sanctioning administrative regulations are based on the design of preventive strategies that, unlike those aimed at social crime prevention (Young 2013), do not seek to impact the causes of crime, but rather are primarily based on situational prevention strategies intended to alter the immediate physical environment in order to reduce the opportunities to commit specific crimes (Crawford and Traynor 2012; Recasens 2012). The supposed bases of such regulations in Spain are scarcely different from those that inspired the 1998 Antisocial Behaviour Order (ASBO) in Britain and its perception of antisocial behaviour, which has contributed to eliminating the traditional distinction between crime and disorder (Crawford 2007, 2009) and has served to enable the contemporaneous exercise of authority (Simon 2007). In short, these regulations could be considered to be among the regulatory instruments to arise with the most recent contemporary shift in the approach towards social crime prevention, focusing much less on the community and much more on the potential offender (Baillergeau and Hebberecht 2012).

In Spain these measures to control the public space have primarily been enacted through municipal ordinances, which, under the pretext of safeguarding civic coexistence, have also served to further segregate various groups of people. As for street prostitution, on which this paper focuses, the civic ordinances passed in the majority of Spanish towns in the early 2000s have entailed the adoption of a soft prohibitionist model. This approach has helped drive sex workers underground in Spain, expelling them from the public space, without reducing the supply of sex work (Arella et al. 2007; Villacampa and Torres 2013a; Vartabedian 2013 ). Civic ordinances have led to the zoning of sex work, in line with the assumptions of reglamentarism (Vartabedian 2011). Moreover, these regulations even call for the administrative sanctioning of sex workers for offering sexual services in public spaces; therefore, rather than a reglamentarist approach, they point to the veiled adoption of a prohibitionist model for managing outdoor prostitution.

\section{The regulatory vacuum regarding sex work in the Spanish legal system}

Spain has not maintained a clear policy on prostitution. This lack of definition in the adoption of a real programme in this area is also apparent in the failure to adopt a specific criminal policy in this regard. Sex work- 
i.e. the voluntary provision of sexual services for money-is not regulated in Spain; it remains in a legal limbo. Traditionally, sex workers have not been allowed to register with the national social security system as such, whether as self-employed individuals or as employees.

Although jurisprudence has considered hostessing - the provision of remunerated services to stimulate the consumption of alcoholic drinks in premises where sexual services are also offered - to be an employment relationship, it has not adopted the same position with regard to the provision of sex work, whether the provider is self-employed or working as an employee (Agustí 2015). It is understood that the object and cause of a hypothetical contract for prostitution or the provision of sexual services cannot be considered legal as it contravenes fundamental human rights. The only exception to this lack of recognition of the employment nature of this relationship, despite calls from both associations representing sex workers and some academics for the recognition of sex workers' employment rights (Juliano 2002; Osborne 2004; Mestre 2004; Mestre and López 2006; Maqueda 2009; Villacampa 2012), is the judgment of Social Court No. 10 of Barcelona of 18 February 2015, which does recognise the provision of sex services as an employment relationship.

Aside from the provisions contained in civic ordinances, the only regulations regarding prostitution in Spain relate to its zoning, establishing rules governing the conditions to be met by the premises in which it is practised, in keeping with the reglamentarist tradition. In light of the failed attempts by some of the country's Autonomous Communities to legalise the provision of services under specific conditions - such as the 2005 Draft Bill Delimiting and Regulating Activities Related to the Provision of Remunerated Sexual Services in Catalonia-regional regulatory activity has been limited to the regulation of the conditions to be met by the premises in which prostitution is practised. Indeed, due to the lack of political support that would have allowed the draft bill regulating prostitution to become law, even Catalonia continued to implement Decree 217/2002, which regulated Public Premises in which Prostitution is Practised. This decree was subsequently revoked and replaced by Decree 112/2010, approving the Regulations on Public Entertainment and Recreational Activities, the content of which is very similar (Barberà 2012). 
From a criminal-law perspective, one could say that Spain has only partially adopted the abolitionist model. The purchase of sexual services is not criminally relevant under the Spanish Criminal Code, unless it involves a minor or a disabled person (Article 188.4). Procuring is always a crime when the person being prostituted is a minor or disabled. If the person prostituting themselves is an adult, incitement to prostitution constitutes a crime when it is achieved by means such as violence, intimidation, deceit or abuse of a position of superiority or of the need or vulnerability of the victim. However, profiting from the prostitution of another person, even with their consent, has been penalised since 2003, meaning that the noncoercive procuring of adults has gained criminal relevance. This notwithstanding, restrictive interpretations of this precept, in both jurisprudence and academia, have led to the criminalisation of acts of noncoercive procuring solely in cases in which the sex worker is exploited professionally, or with the aim of profiting from forced prostitution, or when the procurer takes advantage of a situation of subordination of the prostituted person (Maqueda 2009; Villacampa 2012). With the 2015 reform, the Spanish Criminal Code came to reflect these restrictive interpretations, construing that the procurer "exploits" the situation of prostitution of another when: a) the victim is in a situation of personal or financial vulnerability, or b) burdensome, disproportionate or abusive conditions are imposed on him/her in relation to the practice thereof. Human trafficking for the purposes of sexual exploitation, which, except in cases in which the victims are minors, requires the use of means of commission involving coercion, abuse of specific situations or deceit, is also considered a crime (Article 177.1.b) of the Criminal Code).

Whereas in the criminal-regulatory sphere the abolitionist model has not completely imposed itself, in the political sphere the adoption of the abolitionist discourse is clear. The discourse advocated by the neoabolitionists, which leads to the identification of prostitution with human trafficking, which rejects the suitability and even the possibility of distinguishing between voluntary prostitution and forced prostitution, which identifies prostitution with a form of gender violence, and which considers it to be a practice contrary to the dignity of women, who, far from engaging in the activity consensually are always considered to be victims of their circumstances, has taken root in the Spanish political class. This can be deduced from the content of the report on prostitution in Spain by the Parliamentary Commission on Women's Rights and Equal 
Opportunity, which adopts the postulates of the United Nations Convention for the Suppression of the Traffic in Persons and of the Exploitation of the Prostitution of Others of 1949, regarded as the triumph of abolitionism (Maqueda 2009), and the resolution adopted by the European Parliament on 2 February 2006, which calls for combating the idea that prostitution is work. The Comprehensive Plan to Combat Human Trafficking for Sexual Exploitation adopted by the Socialist government for the 2009-2012 period, the Police Plan to Combat Human Trafficking for the Purposes of Sexual Exploitation adopted in 2013 by the People's Party government, or the recent 2015-2018 Government Plan to Combat the Trafficking of Women and Girls for Sexual Exploitation likewise exemplify the adoption of an abolitionist policy in this regard.

\section{Civic ordinances and sex work}

In light of the lack of regulations in this area at the national or even regional level, municipalities found themselves faced with the need to implement measures to manage the use of public spaces by sex workers who practised their trade in the public space, with the stated goal of ensuring civic coexistence. In fact, the municipal ordinances passed since the early 2000s in many Spanish municipalities are not so new, as they are linked to an old tradition of deep-rooted municipal jurisdiction over urban policing that had already been distilled in earlier police and good governance ordinances (Pemán 2010). In short, in Spain, as in other European countries such as France or Italy, it has been municipalities or local bodies that have taken the lead on the issue of regulations aimed at promoting citizen safety or civic coexistence (Selmini 2005, 2012; Calaresu and Tebaldi 2015), a situation that is not far removed from the preventive criminal policy implemented in Great Britain in the 1980s, which was also driven by local governments (Hugues and Edwards 2005 ).

These ordinances generally regulate civic behaviour or coexistence, placing the central sphere in which citizens socialise and must be protected in the public space. They are legal instruments that regulate rights and duties with regard to individual behaviour in the sphere of relations with others and with the environment in the urban public space. As they are based on a broad understanding of civic coexistence, they usually have clear cross-cutting content (Gracia 2008). First, they protect the urban landscape — urban furniture and areas of public domain - from potentially 
harmful behaviour, as well as the population's peace of mind regarding improper use of the public space or the commission of prohibited activities in it. Second, they address environmental issues. Finally, they aim to protect the dignity of persons by prohibiting discriminatory behaviour. In addition to ordinances intended to be global in nature, some municipalities have passed similar ordinances restricted solely to the regulation of uncivil or antisocial acts (Gracia 2008).

Among the reasons for the adoption of these rules at a municipal level, authorities have pointed to the emergence of new problems in recent years relating to the population's use of public spaces for which there was no legal response (aspects such as drinking in the street) and the exacerbation of traditional problems, such as street prostitution (Gracia 2008; Pemán 2007, 2010). This supposed emergence or exacerbation of problems may be explained, in addition to by the lower tolerance threshold for nuisance in today's individualistic society, by the perception of insecurity, frequently encouraged by the media, with regard to certain antisocial behaviours. Along with these reasons, which could surely be observed in other Western European countries, attention should be drawn to two others, more unique to Spain. First, state legislators have been steadily withdrawing from matters related to public order (Pemán 2007; Ortega 2014). Not only was the obsolete Public Order Act of 1959 replaced by the Citizen Safety Protection Act of 1992, which had less of an impact on matters of public order than its predecessor, but misdemeanours related to public order or the general interest were steadily decriminalised with the criminal reform of 1989 and, especially, the enactment of the 1995 Criminal Code. With this reduction in the national regulation of civic coexistence, there was less support for penalising antisocial behaviour. Second, parallel to the withdrawal of state legislators from matters of citizen safety, the capacity of municipalities to impose sanctions has been strengthened in recent years, favoured by the greater flexibility of the principle of legal reservation in administrative penalty matters resulting from Constitutional Court Judgment 132/2001 and the ensuing reform of the Act Regulating the Bases of Local Government (Pemán 2007; Gracia 2008; Ortega 2014). As a result of the 2003 reform of the aforementioned Act, Title XI thereof now directly enables local ordinances, in the absence of specific sectoral legislation, to establish administrative offences and penalties in the material spheres included in Article 139, namely: a) relationships of coexistence of local interest; b) the use of local services, 
facilities, infrastructure and installations; and c) the use of public space.

The mid-1990s saw a number of municipal initiatives in the sphere of civic responsibility. One such initiative was undertaken by the City Council of Hospitalet de Llobregat, which concluded a pact for civic responsibility that led to the adoption of a project that included enforcement measures, albeit without penalties. However, it was not until 2005, with the passage of the Ordinance on Measures to Foster and Ensure Coexistence in the Public Space of Barcelona that the first civic ordinance per se, with its own system of offences and penalties, was adopted, triggering a succession of similar regulations elsewhere beginning in 2006.

With regard to behaviour related to prostitution, in the absence of legal sectoral regulations on the matter, Article 139 of the Act Regulating the Bases of Local Government permitted town councils to establish administrative offences that, despite affecting personal freedoms, would not violate the principle of legal reservation for the aforementioned reasons. This context explains why, with a view to a supposed preservation of the public space as a sphere of coexistence, in order to prevent minors from seeing sex workers and to prevent hold-ups in road traffic, the councils of the most populous cities in Spain launched an offensive against street prostitution. Since 2005, many provincial capitals and medium-sized cities in Spain have passed civic ordinances. In 2006 they were passed in Valencia, Santander, Vic, Martorell, Mataró and Leganés; in 2007, in Santiago de Compostela and Lleida; in 2008, in Castellón, Seville, Huesca and Ávila; in 2009, in Granada and Guadalajara; in 2010, in Alcalá de Henares, Bilbao, Palma de Mallorca and Málaga; and between 2011 and 2012, in La Coruña, Teruel, Zamora and Puerto de Santa María.

In many cases, these rules have followed the template established by the civic ordinance of Barcelona, which implemented a cross-cutting or global regulation of the various aspects related to civic coexistence. This is true to such an extent that the Citizen Safety and Coexistence Committee of the Spanish Federation of Municipalities and Provinces adopted a model ordinance on citizen safety and civic coexistence that was very similar to the Barcelona City Council ordinance with regard to the provision of sexual services. Under Article 39 of the Barcelona civic ordinance, in effect from 25 January 2006 until its amendment in 2012, it was prohibited to offer, request, negotiate or accept, directly or indirectly, remunerated 
sexual services when these practices impeded or limited the compatibility of the different uses of the public space, as well as to engage in these activities in spaces situated less than $200 \mathrm{~m}$ from schools or educational institutions. Additionally, it was prohibited to engage in paid sexual relations in the public space. In the first version of this provision, behaviour conducted in the immediate vicinity of schools and educational institutions was subject to fines of up to 750 euros, as it was considered to be a minor offence, while engaging in paid sexual relations in the public space was considered a serious offence and could be sanctioned with fines of between 1500 and 3000 euros. In all other cases, individuals were to be informed that the behaviour was prohibited and that, should they persist in their attitude, they could face a penalty for disobedience to authority.

It must be borne in mind that while the ordinance in question penalised the behaviour of offering or negotiating sexual services on public thoroughfares, it penalised the sex workers along with the clients; hence the assertion that the passage of these municipal regulations in Spain reflected the adoption of a soft prohibitionist or pseudo-prohibitionist system (Villacampa and Torres 2013a, b). Unlike pure prohibitionist systems, such as the one adopted in matters of prostitution at the state level by certain states in the United States, sex workers were not criminally penalised but rather received an administrative penalty. This ordinance provided for the implementation of a comprehensive plan to deal with sex work, the effectiveness of which has been questioned (Vartabedian 2011).

The model ordinance, the one in Barcelona, was amended on 31 July 2012 in terms that were highly contested by the city's sex worker organisations, which organised the "Indignant Prostitutes" campaign with the aim of denouncing the consequences they believed the amendment of the ordinance would entail (Vartabedian 2013). This amendment sought to differentiate between the penalties and offences applicable to sex workers and clients with the aim of toughening those related to clients; however, those applicable to sex workers were also toughened in part. Although in the absence of aggravating circumstances, the offer, acceptance and provision of sexual services - behaviours in which sex workers might engage - are considered to be minor offences subject to a fine of up to 300 euros, which may be substituted with another type of penaltyparticipation in a social integration course - the prior warning to be issued to the sex worker by the local police under the previous version of the 
ordinance was removed. In addition, the offer of such services is always penalised, without any margin for negotiations between the client and worker, as had previously been allowed, provided the negotiations did not limit the compatibility of the different uses of the public space. However, it is the client for whom the potential penalties have been toughened the most, as the fines for requesting, demanding or negotiating sexual services can be up to 1500 euros if the activity takes place less than $200 \mathrm{~m}$ from a school or educational institution.

In addition to the civic ordinances of a general nature that, following the Barcelona model, have tackled the practice of street prostitution along with other antisocial behaviour, a second more recent model has emerged in other cities, which have passed specific ordinances in matters of street sex work that are clearly abolitionist and that separate the treatment of this question from the corresponding general civic ordinance. The Ordinance to Combat Prostitution and Trafficking for Sexual Purposes adopted in Seville on 29 April 2011 could be considered the model for this second type of approach. Unlike the model represented by Barcelona's civic ordinance, the Seville ordinance, within the framework of the First Comprehensive Action Plan to Promote the Eradication of Trafficking, Prostitution and Other Forms of Sexual Exploitation, adopted in Seville in 2009 , is clearly based on abolitionist postulates. To this end, it regards prostitution as a manifestation of gender violence and states that it was issued to complement the city's general civic ordinance with the specific aim of preventing behaviour that might promote a discriminatory or degrading image of women, which could be detrimental to coexistence. It identifies the concepts of prostitution and trafficking in accordance with abolitionist postulates and, based on the view of women in situations of prostitution as victims of an extreme form of gender violence, regards them as victims. The logical and most remarkable consequence of this approach is that it does not penalise those who offer sexual services, but rather the clients. Specifically, with the aim of preventing the sexual exploitation of women, protecting minors from seeing sexual services in the street, promoting coexistence and preventing road traffic problems (Article 14), only the acts of requesting, negotiating or directly or indirectly accepting remunerated sexual services in specific public spaces, as well as engaging in paid sexual relations in the public space, are penalised. Moreover, behaviour that may be considered to encourage or promote the consumption of prostitution or other forms of sexual 
exploitation is prohibited. The penalties for clients and those promoting prostitution can be up to 1500 euros for basic offences, but can reach 3000 euros in aggravated circumstances. In addition to these penalties, the ordinance also provides for a series of specific actions for prostitutes, includes measures against sexist advertising, incentivises citizen collaboration and complaints and implements measures to discourage sexual exploitation in public spaces.

Very similar to the Seville ordinance insofar as it is equally comprehensive in its regulation of the phenomenon and likewise establishes administrative penalties for the demand for sexual services, is the Ordinance to Combat Prostitution passed by the city of Murcia on 23 September 2013. The Municipal Ordinance on the Practice of Prostitution on Public Thoroughfares, passed in Valencia on 26 July 2013, likewise takes a similar approach to that followed by the Seville ordinance. However, despite stating that it penalises the clients and persons who facilitate prostitution, it ultimately penalises sex workers in exactly the same terms as those who use their services. The ordinance considers offering and negotiating remunerated sexual services in the public space to be a serious offence when such practices hinder the compatibility of the different uses of the public space, and it penalises the behaviour of sex workers with fines of up to 1000 euros, which can climb to 2000 euros when it is conducted less than $200 \mathrm{~m}$ from a school or educational institution or in places entailing greater vulnerability for the prostitutes.

There are thus two different models of municipal ordinances regulating this matter. The first, and currently the most widely adopted, arose during the first phase of the passage of civic ordinances and imposes a prohibitionist system. The prohibitionist system initially implemented by most of these ordinances was supported in Catalonia by an amendment to the Catalan Highways Act in 2011, banning uses and activities related to the provision of services of a sexual nature on highways, subject to penalties of up to 30,000 euros for both clients and prostitutes. The second model, based on the postulates of the most recent version of the abolitionist model, that is, the so-called Nordic or Swedish model (Skilbrei and Holmström 2011, 2013 ), seeks to impact demand, penalising consumers of sexual services without penalising the sex workers themselves. This latter model may ultimately prevail in local regulations. As will be shown below, it already seems to have prevailed in state regulations, to the extent that some town 
councils have amended the original articles included in their civic ordinances to remove the penalties that can be imposed on sex workers, keeping only those imposed on clients in place, thereby beginning the shift from prohibitionism to abolitionism. This was the case in Lleida, for instance, which amended its ordinance in January 2015. Lleida still prohibits the offering and provision of remunerated sexual services in the public space, but now only penalises the request and receipt of these services. Finally, a third group of cities with municipal civic ordinances pending passage have decided to wait and see the content of the new Citizen Safety Act of 2015 with regard to the practice of street prostitution before proceeding. This is the case of Madrid or Valladolid.

In addition to the effects that the offensive undertaken against street prostitution might have on sex workers, the municipal regulation-and penalisation, where applicable — of the offering of sexual services has led to doubts regarding whether local government, with its limited powers, should be in charge of regulating this matter at all (Gracia 2008). It has been argued that this regulation, whatever its nature, should be passed at a higher level and with the force of law, both to uphold the principle of legal reservation in administrative penalty matters and to harmonise regulations with a view to respecting the principle of equality (Pemán 2010).

\section{Effects of the civic ordinances on sex workers: empirical evidence}

Little empirical research has been conducted in Spain on the effects of the implementation of this type of ordinance on sex workers. Since Pons's (1992) study of the scope and conditions of the practice of prostitution in Asturias, different studies have looked at this reality at a regional level, but most have not analysed the effects of the implementation of these municipal regulations on sex workers. The most recent of such studies include the Seville City Council's study on trafficking, prostitution and other forms of sexual exploitation in that city (Ayuntamiento de Sevilla 2013), which looked at the reality of women prostitutes based on 21 interviews with sex workers, although it did not focus on the effects of the implementation of the city's ordinance on them. Similarly, a study conducted by the Research Group on Prostitution in the Balearic Islands (2014) focused on the migratory process of Nigerian women to Majorca, but did not look at how the implementation of the municipal ordinance 
passed in Palma affected them. In 2015, the Castilla-León Association for the Aid of Drug Abusers (ACLAD) conducted a study on prostitution in Valladolid. Specifically, it analysed the status of the practice of prostitution in the city, comparing the reduced number of sex workers with a previous study from 2006 and noting the decline in both income and the number of clients, although it could not analyse the effects of the implementation of the city's ordinance, as it has yet to be passed.

In Catalonia, however, studies have been published in recent years that analyse the effects on sex workers of the passage of civic ordinances in Barcelona and Lleida. These are complemented by other studies focused on the health conditions surrounding the practice of prostitution, such as those conducted by the Catalan Centre for Epidemiological Studies on Sexually Transmitted Diseases and AIDS in 2009, 2011 and 2014 (Folch et al. 2014), and the social conditions where the activity takes place (Pallarés 2007). In Barcelona, although the study began before the civic ordinance was passed, a second phase of the research took its passage and its effect on the sex workers in the analysis carried out by Arella et al. (2007) into account. That study consisted of 33 in-depth interviews and showed how the human rights violations suffered by sex workers before the civic ordinance was passed had intensified since its passage (Arella et al. 2007). It confirmed that the passage of the regulations had contributed to the zoning of sex work on the street through police pressure and the penalisation of the offering of sexual services. Following the passage of the ordinance, a Barcelona-wide empirical study was carried out with transvestite street sex workers who had emigrated from Brazil, once again using a qualitative methodology (25 semi-guided interviews) (Vartabedian 2013 ). It showed that implementation of the ordinance had led to greater police harassment, which in this case was compounded not only by the illegal nature of the street sex work in which the interviewees engaged, but also by their status as irregular residents (Vartabedian 2013).

The study conducted in Lleida was specifically designed to discover the effects the municipal ordinance had had on sex workers in the city using a mixed quantitative and qualitative methodology consisting of questionnaires administered to a sample of 79 sex workers in the city and in-depth interviews with 20 sex workers offering sexual services on the street (Villacampa and Torres 2013a, b). The women in the sample were asked what effects they believed the passage of the ordinance had had on 
their activity. The majority of the interviewees felt that the ordinance passed four years before had had some form of effect on their activity (66\%), compared with $29 \%$ who felt that it had not. Of these effects, where the corresponding question allowed for open answers, the most commonly cited by far was increased police control (29\%). The second most frequently cited effect was the decline in the number of clients $(17 \%)$, while the third was the decline in income from their services $(13 \%)$ and the fourth, the increased difficulty in negotiating with clients (11\%). The quantitative study suggested that the implementation of the ordinance had not led to substantial changes in the already tough working conditions of the women in the sample and that even effects such as the decline in clients or lower prices paid for their services could be attributed to the financial crisis. However, while the financial crisis may have reduced the number of clients, it did not appear to have reduced the offer of work on the street, as some of the respondents attributed the increased competition on the street to the worsening of these conditions in recent years. The 20 in-depth interviews showed that increased police control was the primary effect of the passage of the ordinance, with sex workers clearly associating the presence of police with the control of their activity. They reported being afraid of the police, in some cases because of the penalty the police might impose on them and in others because of their situation as irregular residents. The interviewees confirmed that the police, and, in particular, the local police, had changed their role, moving from the protective attitude of the past to an eminently controlling one, to the extent that the women had developed escape strategies for when the police arrived. Nevertheless, of the penalties imposed on the sex workers, few were confirmed as having been enforced. The respondents confirmed that the women were fined more than the clients, as they were given direct warnings or penalties simply for waiting in the street for a client or for walking along the street, whereas clients were only fined when they were caught directly engaging in sexual relations in the street.

These studies support the criticism levelled at the municipal ordinances by organisations representing sex workers - such as Hetaria, Aprosex or Sealeer - in that they contribute to leaving women working in street prostitution with no alternative. In short, these regulations push sex workers into situations of illegality, in which they can be penalised and in which, absurdly, they have to provide sexual services in order to pay the fines imposed on them. Consequently, these regulations criminalise 
poverty. Additionally, they may be responsible for effects such as the displacement of criminal behaviour - in this case, antisocial behavioursuch that it ceases to be carried out openly in the street and is instead pushed underground without being reduced, one of the most widely criticised aspects of prevention programmes based on situational prevention techniques (Clarke 2005). This is because the regulations on street sex work contained in the ordinances are based on precisely that type of programme. To this end, the effectiveness of these regulations may be placed in doubt, as they do not reduce the sex work offered, even in the street, but rather have primarily led to the adoption of measures to make it invisible.

\section{A new legal regime regarding street prostitution: adoption of the Swedish model?}

The Spanish Citizen Safety Act (LO 4/2015), passed on 30 March 2015, came into effect on 1 July 2015. This Act replaced the country's previous Citizen Safety Act, which did not address the issue of prostitution. The passage of the Act, which is based on a broad concept of citizen safety that, as has been seen, is not so different from that of the civic coexistence that serves as the basis for the regulations implemented under municipal ordinances, may put an end to the hegemonic role played to date by town councils with regard to the management of public space in relation to the exchange of sexual services.

This is because the article that municipalities have drawn on to regulate this matter-Article 139 of the Act Regulating the Bases of Local Government - allows municipalities to establish offences and penalties in specific areas only in the absence of a sectoral law on the matter. Following the passage of LO 4/2015, such an absence can no longer be claimed, as the Act specifies, with the force of law, which behaviours related to the provision of sexual services on the street should be considered administrative offences. In light of this situation, most municipal corporations will have to adapt the provisions of their regulations to the terms of the new Act. Under the Act, town councils may only introduce specifications or gradations in the table of offences and penalties classified by the Act in order to identify the behaviour or determine the penalties, not to classify offences or penalties (Articles 32 and $41 \mathrm{LO} 4 / 2015$ ). Town councils are only authorised to use ordinances to 
implement the Act's provisions, not to innovate in relation to them. The awareness of the new Citizen Safety Act's potential to impact this matter explains why city councils such as those of Madrid and Valladolid have postponed the passage of their respective civic ordinances.

With the introduction of offences and penalties related to street prostitution, Spain is witnessing a process of recentralisation of the management of citizen safety in public spaces similar to that which took place in Italy with the passage of Act 94/2009 "Disposizioni in materia di sicurezza pubblica"-Provisions relating to Public Security-(Melossi and Selmini 2009; Selmini 2012). As occurred in Italy, this process of recentralisation in Spain may expand the breadth of the criminalisation of behaviour beyond that which would be achieved through the exclusive application of criminal law (Mosconi 2010; Selmini 2012).

With regard to how LO 4/2015 categorises the offence and penalises the offering of sexual services in the street, a vital change took place as the law was being crafted. At least formally, the draft bill wholeheartedly agreed with the prohibitionist approach in matters of street prostitution, toughening even further the offensive undertaken to date by city councils against sex work in the street. However, the abolitionist approach appears to have prevailed at the administrative sanction level, insofar as only clients of prostitution are sanctioned. Thus, the Act ultimately adopts the postulates of neo-abolitionism, i.e. the Nordic or Swedish model, with the strategy of penalising clients to reduce the demand for sexual services.

As is known, the so-called Swedish model was adopted in Sweden with the passage of the 1999 Sex Purchase Act, which introduced the offence of the purchase of sexual services into the Swedish Criminal Code (Ekberg 2004 ), penalising clients with sentences of up to 1 year in prison. The ranks of its supporters have argued that it is an effective model for the abolition of prostitution, as it effectively reduces it without negatively impacting sex workers, whom it regards as victims of this manifestation of extreme gender violence and who, as such, are not penalised (Ekberg 2004; Swedish Institute 2010). This explains why the model has been exported to other Scandinavian countries, such as Norway, Iceland and Finland, as well as other Western European countries, such as the United Kingdom and France, which criminalised the purchase of sexual services in 2013. The Swedish model for the approach to prostitution has also been 
clearly adopted by the EU Parliament through its Resolution of 26 February 2014 on sexual exploitation and prostitution, which opposes the legalisation of sex work, identifies all prostitution with a violation of women's rights - as a form of sexual slavery — and calls for the imposition of the Nordic model. Despite the official "party-line" argument in favour of this model's supposed success, in addition to opposition of an ideological nature, critical voices have been raised in Sweden itself. These voices note that criminally penalising clients has had the effect of displacing, rather than reducing, prostitution, has not reduced human trafficking, and has had negative effects for both clients and, especially, sex workers (Skilbrei and Holmström 2011, 2013; Östergren 2011; Dodillet and Östergren 2012). In the case of the clients, it is more difficult to get them to collaborate as witnesses in criminal cases because they are also offenders. With regard to the sex workers, it increases their stigmatisation, stereotypes them as victims, fosters their distrust of the authorities and increases their vulnerability-by reducing their ability to negotiate the conditions for the provision of their services-because the deterrent effect attributed to the law affects the more socialised clients but not the dangerous ones and because it displaces the sex workers to more isolated areas, where the danger of becoming a victim increases.

In this context of the hegemony of the Nordic model, the Spanish parliament has taken advantage of the passage of LO 4/2015 to adopt it, albeit only formally, as will be seen. Originally, the draft bill of the Citizen Safety Act elevated the soft prohibitionist approach taken to date at the municipal level to a national one. The draft bill penalised with fines of up to 30,000 euros the offer, request, negotiation or acceptance of remunerated sexual services in areas of public transit, in the vicinity of places intended for use by minors or when this behaviour, due to the place where it is carried out, might pose a risk to road safety, although it also provided that the behaviour would not be penalised when the offender was the victim of human trafficking and this status could be accredited. In addition to the fine, the offending sex worker, as well as the client, could be penalised with the loss of the possibility of obtaining residence and work permits if they were in the country illegally or even be expelled from Spain; the extreme nature of the planned regulation's penalising effect on sex street workers was thus clear, since the majority of such workers are irregular migrants. 
The harshness of the planned regulation was reduced when the relevant reports for the draft bill were issued. Curiously, neither the General Council of the Judiciary nor the Prosecution Council had much to say in this regard in their reports and implicitly agreed with the imposition of these penalties on sex workers. The only point the General Council of the Judiciary made was that rather than adopting a preventive model - such as the situational one-geared towards removing the symptoms of the problem, the country should be attacking the causes. It was the report issued by the Secretariat of State for Social Affairs that argued that the penalty envisaged for anyone offering sexual services would merely exacerbate their situation of social exclusion without achieving the stated goal. This argument was subsequently echoed in the Council of State's report. The issue of two reports opposing the penalty on sex workers, along with the adoption of the EU Parliament Resolution of 26 February 2014, ultimately led to the adoption of what appears to be the Nordic-style abolitionist model, whereby only the client is penalised. However, this system has not been adopted in full, as the penalties for sex workers remain in place. Consequently, in response to the question posed in the title of this section, one could argue that the passage of LO 4/2015 marks the formal completion of the shift to the adoption of an abolitionist system, administratively sanctioning clients. However, hidden behind the penalty imposed on sex workers for disobedience is the effective adoption of a soft prohibitionist system at the national level, a system that has been shown to have deleterious effects for sex workers when it has been implemented at the municipal level.

In effect, Article $36.11 \mathrm{LO}$ 4/2015 regards as a serious offence "the request or acceptance by the defendant of remunerated sexual services in areas of public transit, in the vicinity of places intended for use by minors, such as schools, playgrounds or recreational areas accessible to minors, or when this behaviour, due to the place where it is carried out, may pose a risk to road safety". The penalties that can be imposed on clients of street prostitution occurring in the above areas include fines of up to 30,000 euros. However, a similar situation arises with the sex workers, as although the offering of sexual services in these areas is not directly penalised, the same Article 36.11 states that the police will ask the persons offering such services to stop doing so, informing them that failure to comply with this request may constitute the offence of disobedience provided for under Article 36.6 LO 4/2015, which is penalised with the same fine that can be 
imposed on the client. Consequently, although anyone offering sexual services in the street who persists in doing so despite police warnings can no longer be expelled from Spain or refused a residence or work permit on those grounds, he or she can be penalised with a fine of up to 30,000 euros for committing an administrative offence of disobedience. The most serious concern about the possible administrative penalty for the sex worker is the disappearance of the exemption envisaged in the draft bill from the penalty for offering sexual services when the behaviour is carried out by victims of human trafficking.

\section{Conclusions}

Spain has not adopted a clear policy on prostitution beyond the criminalisation of certain behaviours relating to the incitement and sexual exploitation of persons in a situation of prostitution (Article 187 of the Spanish Criminal Code) and the administrative regulation of the conditions to be met by premises where sexual services are offered. The practice of prostitution in general has not been penalised, but neither has it been regulated. This regulatory vacuum has been topped up by municipalities through civic ordinances. In the absence of relevant sectoral laws, town councils, which in principle should not be authorised to determine the basic lines of general policy on matters related to the sex industry, have drawn on the legal authorisation contained in the Act Regulating the Bases of Local Government to establish administrative offences and penalties in spheres such as relations of coexistence of local interest or the use of public space. On this basis, they have adopted situational prevention strategies that penalise both the offer and purchase of sexual services in the public space in order to prevent antisocial behaviour with the stated aim of ensuring that such activities do not interfere with the proper use of specific public spaces and preventing minors from witnessing the exchange of sex for money. The approach adopted by most town councils on this point, with very few exceptions, has been a soft prohibitionist one, insofar as both sex workers and clients are administratively, but not criminally, punished.

Far from putting an end to the offering of sexual services, the stated goal in many cases, this municipal policy has served above all to stigmatise street sex workers even further. There is no evidence that the number of sex workers has declined, but rather quite the opposite, at least according to the perception of the sex workers themselves. The ordinances appear not to 
have impacted the general conditions in which sex workers operate, although they have led to a significant increase in police pressure and control and, thus, to a clear change in the role of the police. Sex workers have been swept out of the public space and rendered invisible, but the causes that might lead people to perform sex work have not been effectively addressed, as the measures undertaken have been limited to impacting the physical or environmental setting rather than tackling the social roots of the problem. In short, safeguarding civic coexistence through the use of administrative law sanctions has served to segregate and control "failed citizens" or "non-citizens", because they are sex workers and, quite often, irregular residents too.

The fact that regulations of sex work in public spaces have been adopted at the municipal level has led to disparities, not only in the types of penalties imposed but also in the breadth of the types of prohibited behaviour and even in the approach to the problem, resulting in a certain shift in some ordinances from a prohibitionist stance to an abolitionist one. With the passage of LO 4/2015, the central role of the municipalities in setting the policy lines on sex work has disappeared. A process of recentralisation has occurred such that it is now regulations with the force of a state law that determine which behaviours may be penalised in this regard.

While on the surface this change might seem like a positive development, in that it will help to standardise municipal policy, the actual regulation passed at the state level will not contribute to the social integration of sex workers. At first glance it may appear to reflect the adoption of an abolitionist approach in keeping with the Swedish model, due to the penalisation of the client. However, closer inspection reveals that hidden behind this supposed adoption of the abolitionist model lies a soft prohibitionism, as street sex workers are to be reminded that they could be penalised for disobedience. What is more, the impacted field continues to be sex work on the street, that is, the type that upsets "orderly citizens"; nothing is said of the types of sex work offered in closed premises or online, which remain in a legal limbo.

With the implementation of the recently passed state regulation, the model has officially become abolitionist, but it is very likely to end up being materially prohibitionist. It continues to be left to town councils, when implementing the provisions of the law regarding sex work, to set limits 
with regard to the application of the offence of disobedience to sex workers who fail to comply with the police's requests. Whatever option town councils adopt in this regard, the application of administrative law sanctions instead of criminal law to the offering or purchase of sexual services, even though it might initially seem more benign, may end up being more onerous, in that it offers fewer guarantees for the offender. This is because the penalty is not imposed by a judicial body but rather the administration, and the level of guarantees for the offender in administrative sanctions procedure has not yet attained the same level as in criminal procedure. Consequently, for example, the statements of the police officers who file the report have probative value with regard to the reported facts whereas in the criminal process they serve only as testimonial evidence. Furthermore, and much more worrying, especially in the context of sex workers, despite the existing modulation of administrative penalties depending on the degree of culpability of the offender, no cause for exemption from administrative responsibility is provided for akin to the general causes of exemption from criminal responsibility. Therefore, a trafficked person forced to offer sexual services on the street by a procurer could end up being penalised for committing an administrative offence of disobedience, as the express mention of the exemption from administrative responsibility of victims of human trafficking included in the draft bill of LO 4/2015 has disappeared.

In light of the above, it can be inferred that the implementation of this system of administrative responsibility will surely contribute to broadening the spheres of responsibility of the individuals involved in this type of behaviour, confirming the collateral effect of expanding the criminal justice system attributed to crime prevention policies (Tonry 2004; Tilley 2005 ). However, it may also paradoxically end up penalising some of the very people whose protection the Swedish model was supposed to ensure, the victims of human trafficking, who could potentially be penalised under LO 4/2015 if they are being exploited through the practice of street prostitution. Given this effect, there is little doubt that the new state regulation may move even further towards the criminalisation of behaviours performed by street sex workers than existing municipal ordinances have already done.

\section{References}


Agustí, J. (2015). Razones para la laboralización de la -libre- prestación de servicios de prostitución por cuenta ajena. IUSlabor, 1(2015), 1-12.

Arella, C., Fernández, C., Nicolás, G., \& Vartabedian, J. (2007). Los pasos (in) visibles de la prostitución. Estigma, persecución y vulneración de derechos de las trabajadoras sexuales en Barcelona. Barcelona: Virus Editorial.

Ayuntamiento de Sevilla. (2013). Estudio sobre la trata, la prostitución y otras formas de explotación sexual en la ciudad de Sevilla. http://www.sevilla.org/ayuntamiento/areas/area-de-familia-asuntossociales-y-zonas-de-especial-actuacion/a-mujer/plan-integral-contra-laprostitucion/estudio-sobre-la-trata-la-prostitucion-y-otras-formas-deexplotacion-sexual-en-la-ciudad-de-sevilla/estudio-sobre-la-trata-laprostitucion-y-otras-formas-de-explotacion-sexual-en-la-ciudad-desevilla. Accessed 7 June 2015.

AQ2

Baillergeau, E., \& Hebberecht, P. (2012). Social crime prevention in late modern Europe. Towards a comparative analysis. In P. Hebberecht \& E. Baillergeau (Eds.), Social crime prevention in late modern Europe. A comparative perspective (pp. 21-36). Brussels: VUB.

Barberà, R. (2012). Aproximación a la prostitución desde la vertiente normativa en Cataluña: la ordenación administrativa local de los establecimientos donde se ejercen actividades de naturaleza sexual. In Villacampa, C. (coord), Prostitución: ¿hacia la legalización? (pp. 285308). Valencia: Tirant lo Blanch.

Barcelona, J. (1995). Seguridad Ciudadana. Enciclopedia Jurídica Básica, vol, IV (pp. 6095-6100). Madrid: Civitas.

Beckett, K., \& Herbert, S. (2010). Banished: the new social control in urban America. New York: Oxford University Press.

Bickford, S. (2000). Constructing inequality: city spaces and the architecture of citizenship. Political Theory, 28(3), 355-376.

Calaresu, M., \& Tebaldi, M. (2015). Local security policies and the 
protection of territory: an analysis of the Italian experience (20072009). City, Territory and Architecture, 2015 (2:1):1-18.

Carro, J. L. (1990). Sobre los conceptos de orden público, seguridad ciudadana y seguridad pública. Revista Vasca de Administración Pública, 27(1990), 9-25.

Clarke, R. V. (2005). Seven misconceptions of situational crime prevention. In N. Tilley (Ed.), Handbook of crime prevention and community safety (pp. 39-70). Cullompton: Willan.

Crawford, A. (2007). Crime prevention and community safety. In M. Maguire, R. Morgan, \& R. Reiner (Eds.), The Oxford handbook of criminology (4th edn., pp. 866-909). Oxford: Oxford University Press.

Crawford, A. (2009). Governing through anti-social behaviour: regulatory challenges to criminal justice. British Journal of Criminology, 49(6), 810-831.

Crawford, A., \& Traynor, P. (2012). La prévention de la délinquance chez les Anglais: from community-based strategies to early interventions with young people. In P. Hebberecht \& E. Baillergeau (Eds.), Social crime prevention in late modern Europe. A comparative perspective (pp. 63-101). Brussels: VUB.

De Lucas, J. (2015). Espacio público y personas: más allá de la ciudadanía nacional. In C. Cierco, R. García \& H. Silveira (coords.), Uso y control del espacio público: viejos problemas, nuevos desafíos. Cizur Menor: Thomson Reuters-Aranzadi.

Dodillet, S., \& Östergren, P. (2012). La Ley sueca sobre la compra de sexo: presuntos éxitos y resultados demostrables. In C. Villacampa (coord), Prostitución: ¿hacia la legalización? (pp. 113-152). Valencia: Tirant lo Blanch.

Ekberg, G. (2004). The Swedish Law that prohibits the purchase of sexual services. Best practices for prevention of prostitution and trafficking in human beings. Violence Against Women, 10(2004), 11871218 . 
Folch, C., Casabona, J., Sanclemente, C., Esteve, A., \& González, V. (2014). Tendencias de la prevalencia del VIH y de las conductas de riesgo asociadas en mujeres trabajadoras del sexo en Cataluña. Gaceta Sanitaria, 28(3), 196-202. doi: 10.1016/j.gaceta.2013.11.004 .

Gracia, R. (2008). Convivencia ciudadana, prostitución y potestad sancionadora municipal. El caso de Barcelona. QDL (Fundación Democracia y Gobierno Local), 17, junio 2008, pp. 99-133.

Hugues, G., \& Edwards, A. (2005). Crime prevention in context. In N. Tilley (Ed.), Handbook of crime prevention and community safety (pp. 14-34). Cullompton: Willan.

Juliano, D. (2002). La prostitución: El espejo oscuro. Barcelona: Icaria.

Light, J. (2002). Urban security from warfare to welfare. International Journal of Urban and Regional Research, 26(3), 607-613.

Maqueda, M. L. (2009). Prostitución, feminismos y derecho penal. Comares: Granada.

Melossi, D., \& Selmini, R. (2009). Modernisation of institutions of social and penal control in Europe: The "new" crime prevention. In A. Crawford (Ed.), Crime prevention policies in comparative perspective (pp. 153-176). Cullopton: Willan

Mestre, R. (2004). Las caras de la prostitución en el Estado español: entre la Ley de Extranjería y el Código Penal. In R. Osborne (Ed.), Trabajador@sdel sexo.Derechos,migraciones y tráfico en el s.XXI (pp. 245-262). Edicions Bellaterra: Barcelona.

Mestre, R., \& López, M. (2006). Trabajo sexual. Reconocer derechos. Valencia: Ediciones Burbuja.

Mosconi, G. (2010). La sicurezza dell'insicurezza. Retoriche e torsioni della legislazione italiana. Studi sulla questione criminale, 2, 75-100.

Ortega, J. (2014). Derechos fundamentales y ordenanzas locales. Madrid: Marcial Pons. 
Osborne, R. (2004). Introducción. In R. Osborne (Ed.),Trabajador@s del sexo. Derechos, migraciones y tráfico en el s. XXI (pp. 19-42). Barcelona: Edicions Bellaterra.

Östergren, P. (2011). Sexworkers critique of Swedish prostitution policy. http://www.petraostergren.com/upl/files/115326.pdf . Accessed 6 June 2015.

Pallarés, J. (2007). Mujeres inmigrantes y trabajo sexual en Lleida. Lleida: Edicions de la Universitat de Lleida.

Pemán, J. (2007). Ordenanzas municipales y convivencia ciudadana: reflexiones a propósito de la Ordenanza de civismo de Barcelona. Revista de Estudios de la Administración Local y Autonómica, 35(2007), 9-55.

Pemán, J. (2010). La política de civismo en los ayuntamientos españoles. Entre policía, acción social y educación cívica. Revista Aragonesa de Administración Pública. 36, 2010, pp. 11-52.

Pons, I. (1992). La cara oculta de la luna: condiciones de vida de las prostitutas en Asturias. Barcelona: Universitat de Barcelona.

Recasens, A. (2012). Social crime prevention policies in Spain from 2000-2010. In P. Hebberecht \& E. Baillergeau (Eds.), Social crime prevention in late modern Europe. A comparative perspective (pp. 321348). Brussels: VUB.

Recasens, A., Cardoso, C., Castro, J., \& Nobili, G. G. (2013). Urban security in southern Europe. European Journal of Criminology, 10(3), $368-382$.

Selmini, R. (2005). Towards città sicure? Political action and institutional conflicto in contemporary preventive and safety policies in Italy. Theoretical Criminology, 9(3), 307-324.

Selmini, R. (2012), Social crime prevention in Italy: A never ending story. In P. Hebberecht \& E. Baillergeau (Eds.), Social Crime Prevention in Late Modern Europe (pp. 209-233). A Comparative 
Perspective. Brussels: VUB.

Simon, J. (2007). Governing through crime. Oxford: Oxford University Press.

Skilbrei, M. L., \& Holmström, C. (2011). Is there a Nordic prostitution regime? Crime \& Justice, 40(2011), 479-517.

Skilbrei, M. L., \& Holmström, C. (2013). Prostitution policy in the Nordic Region: Ambiguous sympathies. Farnham: Ashgate.

Swedish Institute. (2010). Selected extracts of the Swedish government report SOU:49: "The Ban against the Purchase of Sexual Services. An Evaluation 1999-2008". https://ec.europa.eu/antitrafficking/sites/antitrafficking/files/the_ban_against_the_purchase_of_sexua 2008_1.pdf . Accessed 7 June 2015.

Tilley, N. (2005). Introduction: thinking realistically about crime prevention. In N. Tilley (Ed.), Handbook of crime prevention and community safety (pp. 3-13). Cullompton: Willan.

Tonry, M. (2004). Punishment and politics: Evidence and emulation in the making of english crime and control policy. Cullompton: Willan.

Vartabedian, J. (2011). Trabajo sexual en Barcelona. Sobre la gestión municipal del espacio público. Oñati Socio-legal Series, 1(2), 1-13.

Vartabedian, J. (2013). "Tengo mucho placer para enseñarte": sobre travestis brasileñas trabajadoras del sexo y la gestión pública de la prostitución en Barcelona. Quaderns-e Institut Català d'Antropologia, $18(1), 80-97$.

Villacampa, C. (2012). Políticas de criminalización de la prostitución: análisis crítico de su fundamentación y resultados. Revista de Derecho Penal y Criminología, 7(2012), 81-142.

Villacampa, C., \& Torres, N. (2013a). Políticas criminalizadoras de la prostitución en España. Efectos sobre las trabajadoras sexuales. Revista Electrónica de Ciencia Penal y Criminología, 15-06(2013), 6:1-6:40. 
Villacampa, C., \& Torres, N. (2013b). Effects of the criminalizing policy of sex work in Spain. International Journal of Law, Crime and Justice, 41(2013), 375-389.

Wacquant, L. (2009). Punishing the poor: The neoliberal government of social insecurity. Durham: Duke University Press.

Young, J. (2013). Social crime prevention. In E. McLaughlin \& J.

Muncie (Eds.), The Sage dictionary of criminology (3rd edn., p. 424).

London: Sage. 